Journal of Southeast Asian

2013

\title{
Book Review: Ru, by Kim Th
}

Candie Sanderson

University of Montana, candie.s.sanderson@gmail.com

Follow this and additional works at: https://docs.lib.purdue.edu/jsaaea

\section{Recommended Citation}

Sanderson, Candie (2013) "Book Review: Ru, by Kim Th," Journal of Southeast Asian American Education and Advancement. Vol. 8 : Iss. 1, Article 8.

DOI: $10.7771 / 2153-8999.1063$

Available at: https://docs.lib.purdue.edu/jsaaea/vol8/iss1/8

This document has been made available through Purdue e-Pubs, a service of the Purdue University Libraries. Please contact epubs@purdue.edu for additional information.

This is an Open Access journal. This means that it uses a funding model that does not charge readers or their institutions for access. Readers may freely read, download, copy, distribute, print, search, or link to the full texts of articles. This journal is covered under the CC BY-NC-ND license. 


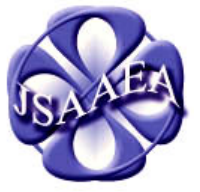

Volume 8 (2013)
Journal of Southeast Asian American

Education \& Advancement

WWW.JSAAEA.org
A peer-reviewed

scholarly journal published by the National Association for the Education \& Advancement of Cambodian, Laotian, and Vietnamese Americans (NAFEA)

\title{
Thúy, Kim. (2012). Ru. New York: Bloomsbury. 160 pp. \$14.00 (Paperback). ISBN: 978-1608198986
}

\author{
Reviewed by \\ Candie Sanderson \\ University of Montana
}

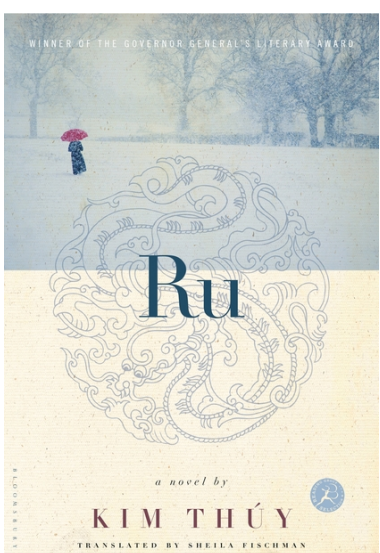

$R u$, by Kim Thúy, was fist published in French in 2009 and received Canada's Governor General Award in 2010; it was then released in 2012 by Random House Canada in an English translation by Sheila Fischman. $R u$ is the first Vietnamese Canadian novel; as such, it explores in a rather short narrative a vast array of themes associated to immigration, such as identity, memory, language, motherhood and family, hardship, survival, renewal, and national History versus personal history. Kim Thúy writes $R u$ as a counterpoint to the political History, censored by the government, that is found in the books, that she herself had to learn in school. Since "the History of Vietnam, written with a capital H, thwarted ... [her] mother's plans" (p. 2) and blew her childhood to pieces, Kim Thúy chose to write her own history of Vietnam, through her personal story: that of an upper-class Vietnamese family who escapes Vietnam by boat after the fall of Saigon in 1975, to finally find refuge, after many trials and tribulations, in the modern Promised Land, in the West, in Québec, Canada.

With the Vietnam War and the boat people experience as its historical background, $R u$ could be a classic real-life immigrant story. However, its originality and value lie elsewhere. Although almost entirely based on autobiographical events, $R u$ is not a memoir, but a novel. It is not merely historical truth Kim Thúy is seeking, but poetic truth. The melody and images contained in the novel are intended to reveal just as much - if not more-about the Vietnamese immigrant experience, as hard facts would. Instead of presenting a chronological account following the focused point of view of a main character, the book makes detours, leaves ellipses, breathes with the ebb and flow of a river of memories that extends its arms to those forgotten by History: old women, broken families, street vendors, children, party-goers, prostitutes, innocent boy soldiers. More than an autobiographical narrative, $R u$ is a song that, through the voice of the one who left, recalls the colors, sounds, and atmosphere of a Vietnam torn to shreds, left behind, "no longer a place but a lullaby" (p. 140). The novel's poetic title is meaningful both in the native and adopted language of its author: "In French, $r u$ means a small stream and, figuratively,

SORERIIGHISRESERVED Readers are free to copy, display, and distribute this article, as long as the work is attributed to the author(s) and the Journal of Southeast Asian American Education \& Advancement, it is distributed for noncommercial purposes only, and no alteration or transformation is made in the work. More details of this Creative Commons license are available at http://creativecommons.org/licenses/by-nc-nd/3.0/. All other uses must be approved by the author(s) or JSAAEA. 
a flow, a discharge — of tears, of blood, of money. In Vietnamese, ru means a lullaby, to lull," the introduction reads.

The book itself follows this dynamic, adopting a poetic voice that remains consistent throughout a hundred and thirteen vignettes of varying length, from a paragraph to a couple of pages. $R u$ presents itself as a succession of fragmented descriptions, narrative episodes, and reflections, a free association of memories, whose order seems to follow the narrator's own thought and reminiscence process, instead of any kind of linear plot or chronology. $R u$ opens, however, in a traditional autobiographical manner, with the birth of the narrator during the Tet offensive in South Vietnam, soon after the new year, in 1968. The first couple of vignettes establish some of the major themes of the novel-motherhood, family, History-but also some of its major stylistic devices: dichotomies and oxymorons. Both the celebration of a renewal and the horrors of war and death preside over the narrator's birth:

I first saw the light of day in Saigon, where firecrackers, fragmented into a thousand shreds, coloured the ground red like the petals of cherry blossoms or like the blood of two million soldiers deployed and scattered throughout the villages and cities of a Vietnam that had been ripped in two. (p. 1)

Following another contrast, that of "the blue of the sky and the blue of the sea" and "heaven and hell" (p. 3), the book then retraces the narrator's journey escaping from Vietnam to Malaysia, on a boat where refugees are piled up in a dark room, paralyzed with fear. The narrative then flashes forward to the narrator's son and his own private war with autism. Kim Thúy frequently goes back and forth in time, asking her readers to follow the book's images and ideas, rather than plot. The following pages deal with the narrator's arrival in Canada, where she as a wide-eyed child is greeted by snow, and generous, curvy Westerners. Here too, the contrast is striking as the narrator compares herself to her teacher: "We were hypnotized by ... her round and generous behind ... We were all angular, bony, hard" (p. 9). The narrative then goes back to the narrator's life in a refugee camp in Malaysia, plagued by flies and maggots, going back and forth between her current and past situation, there again comparing and contrasting the East and the West, the former as a place of hardship, the latter as the land of peace and abundance. Although the reader may have a decent sense of the narrator's journey after reading about those different episodes, she must wait another twenty-five pages to get a better sense of the narrator's life in Vietnam, before her family's escape.

The Nguyens used to be quite affluent, an upper-class, Western-influenced family, until the communist regime came to make an inventory of their possessions, and requisitioned half of their house, building a brick wall in the middle of it. The brick wall in her childhood home is, in the narrator's mind, a smaller version of the one separating the East from the West during the Cold War era. Here again, personal history meets national History. The following vignettes explore that profound divide that tore the country apart, telling the story of two brothers separated by a wall, an ironic chiasmus, "the older child ... [with] the fan without a switch ... the younger the switch without the fan" (p. 34). The narrative also starts to linger on those forgotten by the books, such as "those women who carried Vietnam on their backs while their husbands and sons carried weapons on theirs" (p. 38). Suffering yet heroic women are many in $R u$ : the delicate Vietnamese woman carrying on her frail body the hardship of her country is a recurring image, whether it takes the form of a prostitute, a young girl masturbating soldiers for a meal, or old women laboring in the fields. 
The next dozen of vignettes constitute one of the few easily recognizable blocks in the book. They focus on the story of Uncle Two, "a charismatic, happy-go-lucky young man" (p. 46) and conniving centrist politician, and his daughter Sao Mai, princess to her father's eyes, and in the shadow of whom the narrator is bound to remain. The narrator depicts with fascination Uncle Two's extravagant life: the constant parties, ever changing women, memories of his education in France, and "music of the Doors, Sylvia Vartan, Michel Sardou, the Beatles or Cat Stevens" (p. 48). She contrasts Uncle Two's family's way of life-where rice may be lacking, but where "a festive aura, a sense of decadence and thrill" (p. 48) always fills the house - to her own family's, where parents are parents, not kings or queens, and children must learn to go through life with strength and resolution. Here again, the reader can see between the lines the two Vietnams: one stern, independent, and traditional, and the other decadent, in love with the West. While the narrator's mother courageously protects her children, Uncle Two denounces his, for fear of political payback.

The following episodes deal with the narrator's family, her repressed mother, her father who chooses to live solely in the present and without regret, Aunt Five and her filial devotion, Aunt Six and her American dream success story. The narrator's family is constantly compared to the ideal family of the American Dream - an ideal the narrator is longing for. This readiness to adopt the Western model triggers some questioning in terms of identity. The narrator recounts her conversation with a Vietnamese waiter in Canada, who thought she was "too fat to be Vietnamese" (p. 77):

The American dream made me believe I could have everything ... But the young waiter reminded me that I couldn't ... that I no longer had the right to declare I was Vietnamese because I no longer had their fragility, their uncertainty, their fears. And he was right to remind me. (p. 77)

About halfway through the novel, the narrative reaches a pivotal point: from a longing towards the West, the narrator shifts to a troubled and melancholy remembrance of the East. The second half of the novel thus becomes less personal and autobiographical, but focuses more on Vietnam during the American occupation and after. There, the reader will find some of the more political and historical concerns of the novel, if only in glimpses: the children of the GIs left behind after their fathers went back West, the American soldiers lost in a country they don't know, Monsieur An sent to reeducation camp by the communists, the monochromatic life and communist propaganda taught in schools, etc.

In spite of the nonlinear and rather reflective structure of this part of the novel, it is possible to identify some groupings of episodes based on thematic musings. The first group, from pages ninety-six to one hundred and three, reflects upon love, the mind, and the body, focusing on sensual memory, and the different types of love, from the feverish amorous state of lovers, to the unconditional love of mothers. These considerations about love are accompanied by some about language - another recurring theme in the book. "In the case of Vietnamese, it is possible to classify, to quantify the meaning of love through specific words..." (p. 96). Language and emotion are systematically associated: words carry feelings.

The next dozen of pages reflect upon a sense of home. They recall the colors, sounds and smells of Vietnam: the delicious soups served for breakfast, the songs of the street vendors, the dark alleyways in which mentally impaired Aunt Seven wandered. The themes exile, newfound identity, and longing for the past permeate those episodes and are rendered strikingly through 
mundane images. In a particularly memorable episode, the narrator recognizes with great emotion her life in the West in the smell of Bounce fabric softener, imprinted in her lover's shirt. She then designs in Paris a perfume that encompasses her own notion of home.

The following vignettes focus on Vietnamese women, describe Westerners' fascination for their ao dàis, "that hypocritically modest and deceptively candid garment" (p. 115); the narrator pities American soldiers looking for solace and their lost youth in the arms of Vietnamese women, admires and grieves for young women prostituting themselves, bearing on their bodies invisible scars from the humiliation, but also "becoming untouchable, invincible," stripping money of its destructive power, using it to their advantage. Those women, the author writes, "behind their dreamy bodies and their youths, they carried all the invisible weight of Vietnam's history, like the women with hunched backs" (p. 125). The silent role women played during the war and occupation is a recurrent theme in immigrant Vietnamese literature.

The last pages of the novel read like a present reflection on memory, traces left by history and History, family, the fate of the different characters, and identity. The author sums up her situation as an immigrant in exile in a country that she loves and has adapted to and yet is not hers. Uniting for a moment with another Vietnamese Canadian man around the vaccination scar they share from their past in Vietnam, Kim Thúy writes, "In one second we had seen our own ambivalence, our hybrid state: half this, half that, nothing at all and everything at once" (p. 132). This shifting identity is accepted without bitterness. From contemplating her own fate, the narrator moves onto Vietnam's: what would an archeologist from the future think if he found the diamonds hidden in the acrylic bracelet now dissolved? Traces are being erased: the story of the mother hiding diamonds in a bracelet to protect the family's last riches as they escaped a regime that despised them is bound to be lost. There lies perhaps the purpose of the book, the task of the writer: to record those traces of history, to remember the past so that one day, out of its ashes, the future can be reborn. The novel ends on the image of the Phoenix, on the hope for a renewal, both for the family, the next generation, and the country left behind. Vietnam will again spread its wings, the author tells us, as "one horizon always hides another and it goes on like that to infinity, to the unspeakable beauty of renewal, to intangible rapture" (p. 140). This rapture the writer is striving to capture, so that she can infuse love and grace into "everyday life" (p. 141).

Like Vietnam, $R u$ is divided between a melancholy for the East and an excited fascination of the West. Dichotomies, contrast, and antithetic couples fill the novel, and reunion seems hardly possible. Tension permeates the poetic voice, a voice heavy with history and personal memory. In its one hundred and forty one pages, $R u$ tries to encompass a multitude of stories: that of mothers, daughters, sons, abused little girls, hunched-backed old women, men deprived of freedom, of comfort, of the ability to look ahead, that of the fragile East and the opulent West. However, just as the narrator chose to stay in her cousin Sao Mai's shadow, Kim Thúy makes the conscious choice of telling us about those left aside, those who remained in the shadows of the grand historical narrative. She is concerned with the ordinary-the fact that "everyday life" is the very last word of the novel is indeed telling - the individual stories, the vignettes hidden behind the life-size photos we all have seen. $R u$ is a stream, not an ocean. The song the author decides to sing encompasses bits and pieces from her journey: originating in Vietnam, the stream runs all the way to the West, carrying with it forgotten objects-French lace brassieres, acrylic bracelets, silver-rimmed antique bowls - and stories.

One could reproach $R u$ with its naïve view of the West as a land of generous "angels" ( $p$. 22) and unending abundance. The postcolonial scholar may be surprised to find little trace of discomfort about having to adapt to Western culture, and virtually no interrogation of the West 
as a welcoming Promised Land taking in the poor refugee of the broken East with open arms. At no point does the narrator wonder if Canadian families are inviting her out of pity, or curiosity; at no point does she explicitly question the consequences of Western presence in Vietnam; at no point does she seem to be longing for a little Vietnam in her new country. While her name was meant to be the continuation of her mother's, there is no such continuum between her and her sons, who bear American names. If Vietnam is remembered, it is only as a lullaby to be hummed in idleness, while waiting for a traffic light ${ }^{1}$. The narrator appears to have followed her father's advice to "never regret what we've left behind." (p. 99). The fact that Kim Thúy decided to write this novel in French, in spite of her knowledge of Vietnamese, is proof of her perfect acculturation. Just like Vietnam developed two languages to tell two different realities, that of the war in the North, that of the American occupation in the South, the author developed her own poetic language to tell of her country and immigrant experience, and that language starts where her story ends, in the West. It is through her adopted language that Kim Thúy chooses to sing about her life and that of "those who have walked before [her], for [her]" (p. 140).

$R u$ is an enjoyable and melodious tale that will please those with a taste for classic immigrant stories, vignettes, and poetic language. Postcolonial scholars looking for a critical, matter-of-fact testimony of the Vietnam War and the Vietnamese immigrant experience will find little material in this novel. The book is remarkable perhaps precisely because of the fact that it chooses to avoid explicit political or historical considerations - or at least to develop them in length. What Kim Thúy has to say resides in the small and the mundane: the book's project isn't to encompass post-war Vietnam, but simply to record brief impressions and memories, so the song of those who stayed in the shadow isn't forgotten.

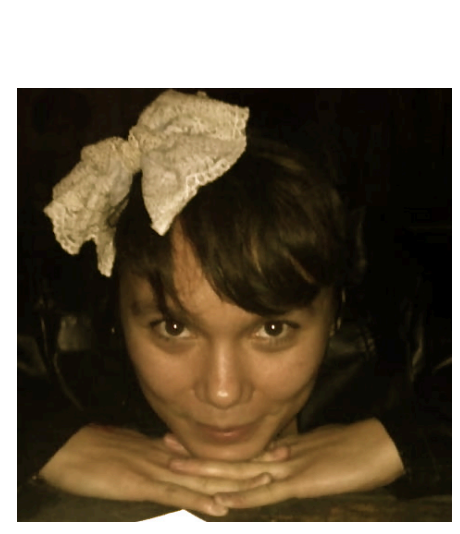

\section{About the Author}

Candie Sanderson is an MFA candidate at the University of Montana. A French native, she holds an M.A in comparative literature from La Sorbonne Nouvelle and attended UC Berkeley as an exchange student. Her research interests include women and gender studies, migration narratives, French and American Vietnamese memoirs, post 9/11 American literature, and French post-structuralism. She is currently working on a memoir based on her mother's life in Vietnam during the French occupation. Her fiction has appeared in Two Serious Ladies and CLAM.

\footnotetext{
1 "Thúy began thinking of the book during the weary drives home from her restaurant-she often nodded off at red lights because of the late hours, she says, and after a couple of fender benders, she began making shopping lists in order to stay awake. 'And I don't know what happened, maybe it was a longer light or something like that ... I turned a book over and started writing, and that's how Ru came to be." Interview of Kim Thúy by NPR Staff, $A$ Refugee's Multilayered Experience in 'Ru.' NPR. November 24, 2012.
} 


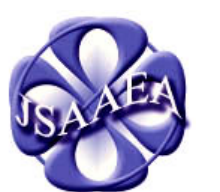

Volume 8 (2013)

\section{Journal of Southeast Asian American Education \& Advancement}

\author{
WwW.JSAAEA.org
}

\section{Editor}

Dr. Wayne E. Wright

University of Texas, San Antonio

\author{
Associate Editors \\ Dr. Chhany Sak-Humphry \\ University of Hawaii at Manoa
}

Dr. Phitsamay Sychitkokhong Uy

University of Massachusetts, Lowell

\section{Book Review Editor}

Dr. Vichet Chhuon

University of Minnesota

\section{Creative Works Editor \\ Bryan Thao Worra \\ Lao Assistance Center}

Special Advisor

Gregory Green

Curator, Echols Collection on Southeast Asia, Cornell University Library

Journal Manager

Sovicheth Boun

University of Texas, San Antonio
A peer-reviewed

scholarly journal published by the

National Association

for the Education \&

Advancement of

Cambodian, Laotian,

and Vietnamese

Americans (NAFEA)

Comments and questions for the editorial staff may be directed to jsaaea@1ists.sis.utsa.edu

\section{Editorial Review Board}

\author{
Dr. Steve Arounsack \\ California State University, Stanislaus \\ Dr. Phala Chea \\ Lowell Public Schools \\ Dr. Loan Dao \\ University of Massachusetts, Boston \\ Dr. Changming Duan \\ University of Missouri, Kansas City \\ Dr. Jeremy Hein \\ University of Wisconsin - Eau Claire \\ Dr. Samlong Inthaly \\ Minneapolis Public Schools \\ Dr. Kevin K. Kumashiro \\ University of Illinois, Chicago
}

Dr. Carl L. Bankston III

Tulane University

Dr. George Chigas

University of Massachusetts, Lowell

Dr. Hien Duc Do

San Jose State University

Dr. Sophal Ear

U.S. Naval Postgraduate School

Dr. Nancy H. Hornberger

University of Pennsylvania

Dr. Peter Nien-Chu Kiang

University of Massachusetts, Boston

Dr. Ha Lam

Arizona State University 


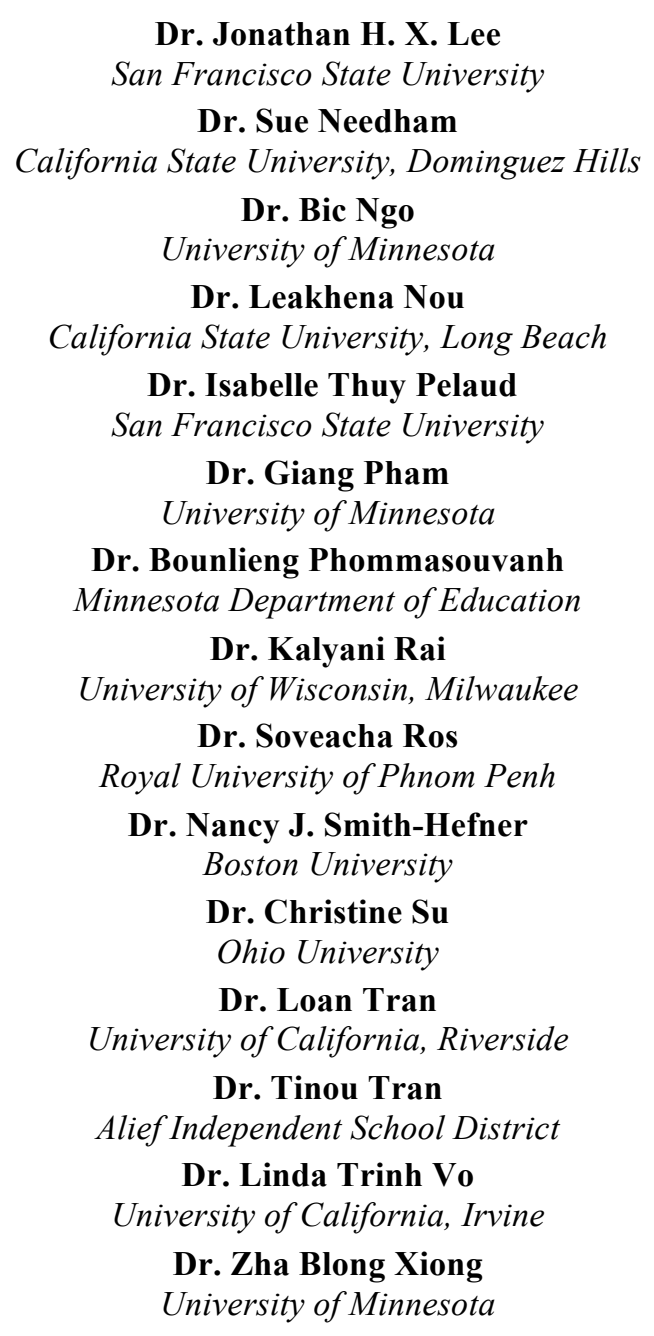

Dr. Jonathan H. X. Lee

Dr. Sue Needham

Dr. Bic Ngo

Unersity of Minnesota

ia State University, Long Beach

Dr. Isabelle Thuy Pelaud

Dr. Giang Pham

University of Minnesota

Dr. Bounlieng Phommasouvanh

Dr. Kalyani Rai

Dr. Soveacha Ros

Royal University of Phnom Penh

Boston University

Dr. Christine Su

Ohio University

Dr. Tinou Tran

Dr. Linda Trinh Vo

University of Minnesota

Dr. Stacey Lee

University of Wisconsin, Madison

KimOanh Nguyen-Lam

U.S. Department of Education

Dr. Max Niedzwiecki

Daylight Consulting Group

Dr. Clara Park

California State University, Northridge

Dr. Mark Pfeifer

SUNY Institute of Technology

Dr. Loan T. Phan

University of New Hampshire

Dr. Karen Quintiliani

California State University, Long Beach

Dr. Angela Reyes

Hunter College, The City University of New York

Dr. Fay Shin

California State University, Long Beach

Dr. Cathy J. Schlund-Vials

University of Connecticut, Storrs

Dr. Yer J. Thao

Portland State University

Dr. Myluong Tran

San Diego State University

Dr. Khatharya Um

University of California, Berkeley

Dr. Terrence G. Wiley

Center for Applied Linguistics

Dr. Kou Yang

California State University, Stanislaus

\section{Doctoral Student Editorial Review Board}

Virak Chan

University of Texas, San Antonio

Annie BichLoan Duong

San Joaquin County Office of Education

Peter Tan Keo

Columbia University

Monirith Ly

Texas State University-San Marcos

Hoa Nha Nguyen

Boston College

Vanna Som

Harvard University

Krissyvan Truong

Claremount Graduate University

Yang Sao Xiong

University of California, Los Angeles
Keo Chea-Young

University of Pennsylvania

Ketmani Kouanchao

California State University, Fullerton

Ravy Lao

University of California, Santa Barbara

Thien-Huong Ninh

University of Southern California

Malaphone Phommasa

University of California, Santa Barbara

Alisia Tran

University of Minnesota

Silvy Un

University of Minnesota

Yeng Yang

University of Texas, San Antonio 